\title{
PROFIL KEMAMPUAN KOMUNIKASI MATEMATIS PESERTA DIDIK DALAM PEMECAHAN MASALAH SOAL CERITA
}

\author{
Chusnul Ma'rifah, Cholis Sa'dijah, Subanji dan Toto Nusantara \\ MAN 3 Malang \\ Universitas Negeri Malang \\ e-mail: chusnulmarifah85@gmail.com
}

\begin{abstract}
Abstrak
Penelitian ini bertujuan mendeskripsikan kemampuan komunikasi matematis peserta didik dalam menyelesaikan soal cerita pada materi barisan dan deret. Penelitian ini bersifat deskriptif kualitiatif serta menggunakan metode survey. Subjek dalam penelitian ini adalah 15 peserta didik MAN 3 Malang yang terbagi dalam kelompok berkemampuan komunikasi matematis tinggi, sedang, dan rendah. Dari masing-masing kelompok, diambil satu subyek untuk dideskripsikan kemampuan komunikasi matematisnya. Hasil menunjukkan bahwa peserta didik dengan kemampuan komunikasi matematis tinggi memiliki kemampuan komunikasi matematis yang baik dalam representasi penyelesaian masalah soal cerita dan dalam mengomunikasikan hal-hal yang berkaitan dengan soal dengan simbol matematis. Untuk peserta didik berkemampuan komunikasi matematis sedang, cenderung melakukan kesalahan dalam menulis representasi penyelesaian masalah, serta sudah dapat menuliskan hal-hal yang diketahui, ditanya, dan kesimpulan dengan menggunakan simbol matematis secara benar. Adapun untuk peserta didik dengan komunikasi matematis rendah, bawah belum dapat memenuhi keduanya.
\end{abstract}

Kata kunci: Komunikasi Matematis, Pemechan Masalah; Soal Cerita Barisan dan Deret

\begin{abstract}
This study aims to describe the mathematical communication skills of students in contextual word problems on sequences and series. This study used descriptive qualitative. The subjects in this study were 15 students of MAN 3 Malang who were divided into three groups: excellent, medium, and low mathematical communication ability. From each group, one subject was taken to describe their mathematical communication skills. The results show that students with excellent mathematical communication skills also have excellent mathematical communication skills in representing solving world problems and in communicating things related to world problems by using mathematical symbols. The students with medium mathematical communication skills show mistakes in writing representations of solving world problems yet still able to write things that are known, asked, and concluded using mathematical symbols correctly while the students with low mathematical communication skills weren't qualified in both of skills.
\end{abstract}

Keywords: Mathematical Communication, Daily Problems of Sequence and Series 


\section{PENDAHULUAN}

Tujuan pembelajaran matematika antara lain meningkatkan kemampuan penalaran, komunikasi, koneksi, representasi, dan pemecahan masalah (Novianti, 2017; Susanti, 2017). Diantara salah satu tujuan pembelajaran tersebut, terdapat komunikasi yang merupakan bagian penting dari matematika (NCTM, 2000; Nofrianto, A., Maryuni \& Amri, 2017). Hal ini juga sesuai dengan standar isi untuk satuan pendidikan dasar dan menengah mata pelajaran matematika dalam Peraturan Menteri Pendidikan Nasional No. 21 Tahun 2016 tentang standar isi yang menyebutkan bahwa salah satu kompetensi yang harus dimiliki peserta didik dalam berlajar matematika adalah memiliki kemampuan mengomunikasikan gagasan matematika dengan jelas dan efektif.

Komunikasi adalah proses penyampaian informasi, ide, emosi, dan keterampilan melalui penggunaan simbol seperti kata-kata, gambar, angka, dan lainnya (Viseu \& Oliveira, 2012; Triana, \& Zubainur, 2019). Selanjutnya, Hirsche \& Cotton (2008) menyatakan bahwa komunikasi matematika membantu dalam membangun makna ketika peserta didik melakukan proses berpikir dan bernalar, lalu mengomunikasikan ide matematis mereka secara lisan maupun tulisan sehingga pemahaman konsep berkembang. Dengan demikian dapat dikatakan komunikasi memegang peranan cukup penting dalam matematika (Viseu \& Oliveira, 2012; Kaya \& Aydın, 2016.). Hal ini dikarenakan komunikasi dalam matematika membantu peserta didik merefleksi, mengklarifikasi, dan mengembangkan ide serta pemahaman matematisnya (Walk, Congress, \& Bansho, 2005).

Salah satu aspek komunikasi adalah menulis (Qohar \& Sumarmo, 2013). Menulis merupakan suatu aktivitas yang dilakukan peserta didik dalam mengungkapkan dan merefleksikan pemikirannya, dapat melalui media kertas, komputers, ataupun media yang lain. Menulis dapat dikatakan sebagai alat berpikir yang sangat bermanfaat dan suatu kegiatan yang kreatif. Sebab melalui menulis, peserta didik dapat mentransfer pengetahuan dan pemahaman yang dimilikinya dalam bentuk tulisan. Komunikasi matematika tulis adalah penyampaian ide matematis dengan menggunakan simbol, gambar, kosakata, dan notasi beserta strukturnya dengan atau tanpa adanya perubahan dalam bentuk tulisan antara dua orang atau lebih sehingga pesan lewat ide yang dimaksud dapat dipahami (Riasari, 2018).

Pembelajaran matematika sebaiknya dapat memberikan kesempatan kepada peserta didik untuk mengembangkan kemampuan komunikasi yang meliputi (NCTM, 2000): (1) mengorganisasi dan menggabungkan pemikiran matematis melalui komunikasi, (2) mengomunikasikan pemikiran matematis yang sesuai serta jelas baik kepada teman, guru, maupun pihak lain, (3) menganalisis dan mengevaluasi strategi dan pemikiran matematis dan (4) menggunakan bahasa matematika untuk menyajikan ide matematis 
secara tepat. Sedangkan menurut Mahmudi (2017) kemampuan komunikasi matematis adalah kemampuan untuk mengekspresikan ide-ide matematika secara koheren kepada teman, guru, dan lainnya melalui bahasa lisan dan tulisan. Dengan menggunakan bahasa matematika yang benar untuk berbicara dan menulis tentang apa yang mereka kerjakan, peserta didik akan mampu mengklarifikasi ide-ide mereka dan belajar bagaimana membuat argumen yang meyakinkan dan mempresentasikan ide-ide matematika.

Terdapat beberapa penelitian yang telah dilakukan mengenai komunikasi matematika. Asmana (2018) menyatakan pada dasarnya setiap peserta didik memiliki kemampuan matematika yang berbeda sehingga kemampuan komunikasi yang dimiliki juga berbeda. Penelitian yang dilakukan Asmana tersebut menyimpulkan jika terdapat hubungan antara komunikasi dengan kemampuan matematika. Adapun peserta didik yang memiliki kemampuan tinggi memiliki komunikasi matematis yang baik dan dapat menyelesaikan masalah persamaan dan pertidaksamaan linier satu variable dengan memperoleh hasil akhir yang benar. Hasil penelitian yang lain mengenai komunikasi matematika adalah terdapat perbedaan dalam karakteristik komunikasi matematis peserta didik antara dalam bentuk tertulis dan bentuk lisan yang merujuk pada aspek keakuratan, kelengkapan, dan sistematis (Wardhana, 2018). Berikutnya penelitian yang dilakukan oleh Lutfianannisak (2018) yang menyatakan kemampuan komunikasi tulis peserta didik pada materi fungsi komposisi yang ditinjau dari kemampuan matematika masih kurang dan diperoleh hasil jika peserta didik kemampuan tinggi, sedang, dan rendah dapat memenuhi 3 indikator dari 4 indikator NCTM.

Soal cerita banyak ditemukan dalam pembelajaran matematika di kelas dan erat kaitannya dengan kemampuan komunikasi matematis. Soal cerita yang terdapat dalam matematika menurut (Oktaviana, 2017; Aminah\&Kurniati; 2018) adalah merupakan persoalan-persoalan yang terkait dengan permasalahan-permasalahan dalam kehidupan sehari-hari yang dapat dicari penyelesaiannya dengan menggunakan kalimat matematika. Namun berdasar fakta di lapangan diperoleh masih terdapat lemahnya kemampuan peserta didik dalam memahami maksud soal dan kurangnya keterampilan menyusun rencana penyelesaian soal cerita dengan kalimat matematika (Rohid, Suryaman, \& Rusmawati, 2019; Fitriatien, 2019). Hal ini dikarenakan pembelajaran matematika dalam soal cerita di kelas masih mengandalkan cara yang diajarkan guru dalam kelas dan soal yang diberikan guru cenderung kurang kontekstual, sehingga potensi untuk mengembangkan pemikiran peserta didik masih banyak menemui kendala.

Komunikasi matematis dan soal cerita matematis adalah bagian matematika yang perlu untuk ditumbuhkembangkan pada peserta didik dan menarik untuk dilakukan penelitian. Tujuan penelitian ini adalah untuk mendeskripsikan kemampuan komunikasi matematis tertulis peserta didik pada soal cerita pada materi barisan dan deret. 


\section{METODE}

Penelitian ini merupakan penelitian deskriptif dengan menggunakan pendekatan kualitatif. Pemilihan subjek dalam penelitian ini adalah 15 peserta didik MAN 3 Malang yang memiliki tingkat kemampuan matematika tinggi, sedang, dan rendah berdasarkan nilai tes yang dilakukan. Dari masing-masing tingkat tersebut diambil satu peserta didik yang mewakili untuk di deskripsikan kemampuan komunikasi matematisnya. Adapun soal cerita pada penelitian ini adalah soal cerita yang bersifat kontekstual dan dirancang berdasarkan keadaan yang dapat terjadi di tempat penelitian.

Instrumen penelitian yang digunakan dalam pengumpulan data meliputi: (1) instrument utama adalah peneliti sendiri; (2) instrumen pendukung antara lain: (a) soal uraian cerita masalah barisan dan deret untuk mengetahui kemampuan komunikasi matematis tulis peserta didik yang terdiri dari dua soal cerita yang telah divalidasi, dan (b) pedoman wawancara digunakan sebagai pedoman pertanyaan dalam wawancara berdasarkan pekerjaan peserta didik dalam tes.

Kemampuan komunikasi matematis peserta didik dikatakan memiliki kemampuan kurang jika ia belum bisa memenuhi dua standar komunikasi menurut NCTM (2000), yaitu: (1) mengomunikasikan pemikiran matematis secara koheren dan jelas kepada teman sebaya, guru, maupun pihak lain dan (2) menggunakan bahasa matematika untuk menyajikan ide matematis secara tepat. Indikator komunikasi tersebut dapat dilihat pada Tabel 1.

\section{Tabel 1. Indikator Komunikasi Matematika Tulis}

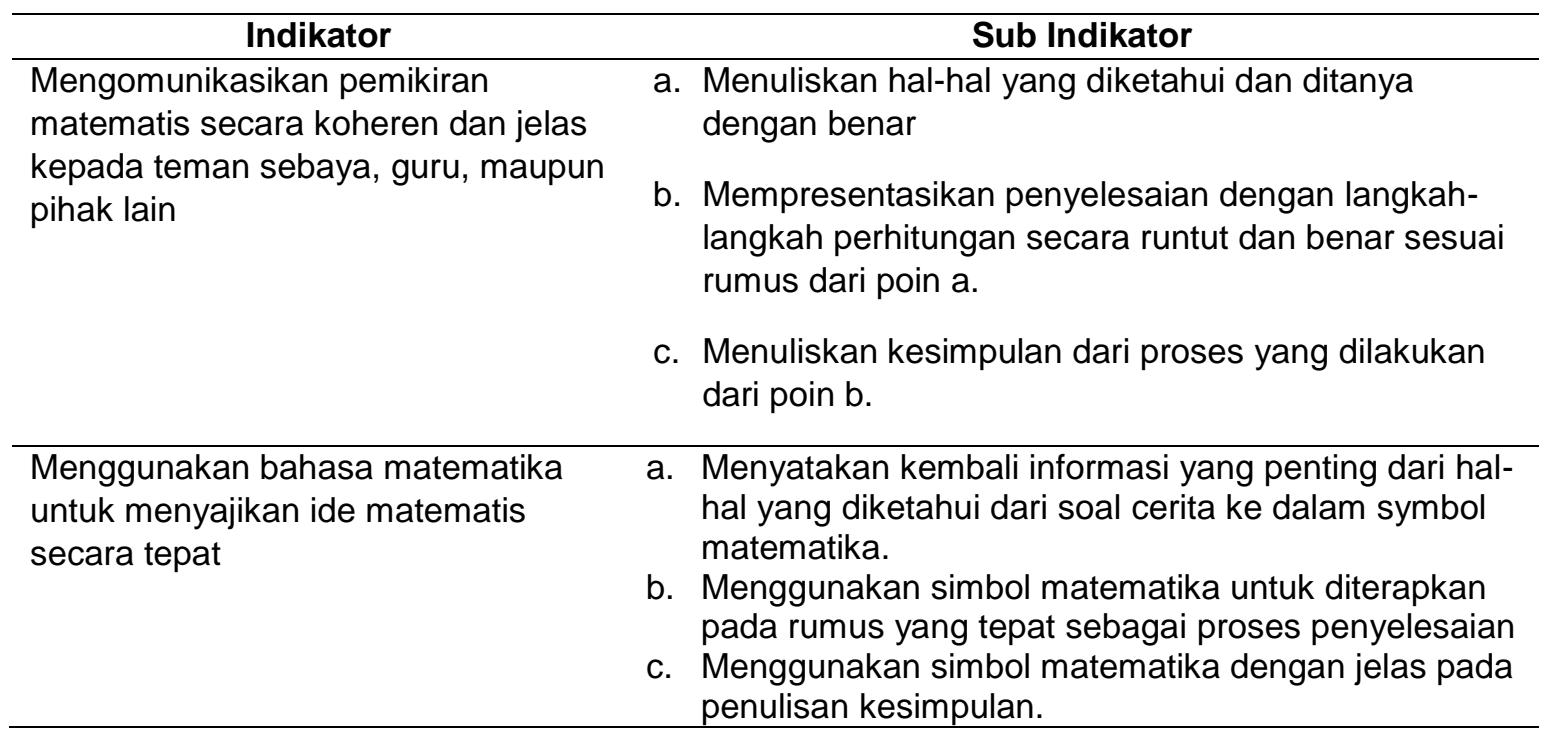

(Adaptasi dari NCTM, 2000)

Teknik pengolahan data terhadap skor kemampuan komunikasi matematis peserta didik dapat dilihat pada Tabel 2. 
Tabel 2. Pedoman Penskoran Kemampuan Komuniksi Matematis

\begin{tabular}{cl}
\hline Skor & \multicolumn{1}{c}{ Kriteria } \\
\hline 4 & Respon lengkap, benar dan jelas, sajian rumus dan perhitungan lengkap dan logis, \\
3 & Respon benar dan jelas, sajian rumus dan perhitungan lengkap. \\
2 & Respon benar dan jelas, sajian rumus dan perhitungan kurang lengkap \\
1 & $\begin{array}{l}\text { Respon tidak benar dan tidak jelas, sajian dan perhitungan kurang tepat } \\
\text { Respon tidak efisien, misinterpretasi (tidak ada jawaban apapun/lembar jawaban peserta } \\
\text { didik kosong) }\end{array}$ \\
\hline
\end{tabular}

(Adaptasi dari Wijayanto, Fajriah \& Anita, 2018)

Adapun katagori pencapaian komunikasi matematis peserta didik dengan menggunakan pedoman pada Tabel 3.

Tabel 3. Katagori Pencapaian Kemampuan Komunikasi Matematis Peserta didik.

\begin{tabular}{cc}
\hline Pencapaian Komunikasi Matematis (\%) & Kategori \\
\hline $0-33$ & Rendah \\
$65-34$ & Sedang \\
$66-100$ & Tinggi \\
\hline
\end{tabular}

\section{HASIL DAN PEMBAHASAN}

Rekapitulasi data kemampuan komunikasi matematis peserta didik disajikan dalam bentuk digram lingkaran seperti pada Gambar 3.

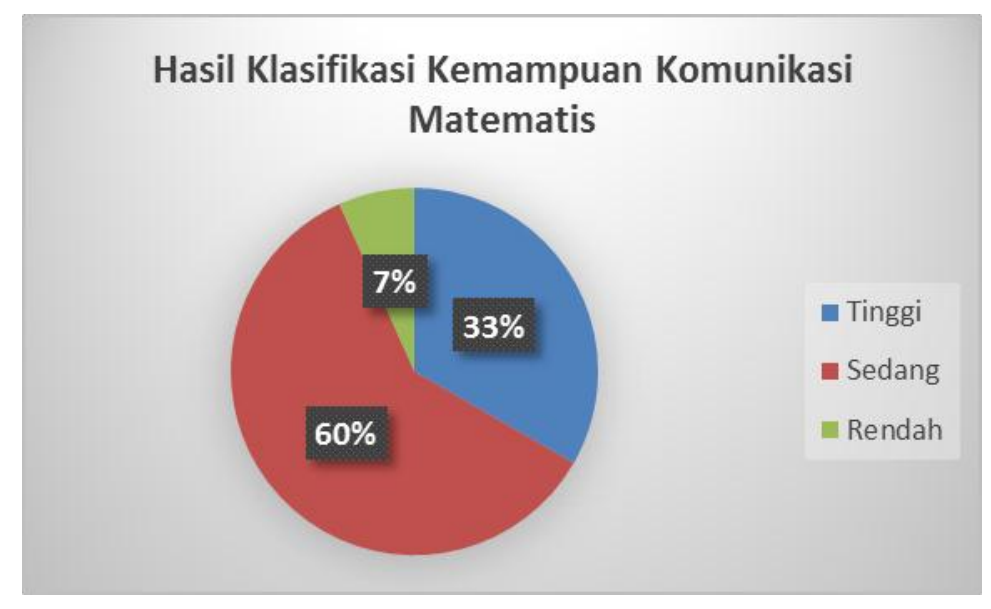

Gambar 3. Hasil Klasifikasi Tes Kemampuan Komunikasi Matematis Peserta Didik

Gambar 3 menunjukkan bahwa dari 15 peserta didik yang mengerjakan soal tes, terdapat tiga katagori pencapaian kemampuan komunikasi matematis siwa. Katagori tersebut meliputi $40 \%$ peserta didik dengan kategori kemampuan komunikasi matematis tinggi yakni sebanyak 5 peserta didik, 53,3 \% peserta didik dengan kategori kemampuan komunikasi matematis sedang sebanyak 9 peserta didik dan 6,7\% peserta didik dengan kategori kemampuan komunikasi matematis rendah dengan 1 peserta didik. Berdasar pengklasifikasian tersebut.

Peserta didik kelompok atas (SA) mulai mengerjakan soal nomor satu dengan menuliskan semua informasi yang diketahui pada soal dalam simbol matematis tanpa menuliskan kaitan simbol dengan masalah pada soal. Peserta didik SA juga menuliskan 
hal yang ditanyakan dengan simbol matematis dan diberi tanda tanya. Gambar 4 adalah hasil jawaban peserta didik SA pada soal nomor 1.

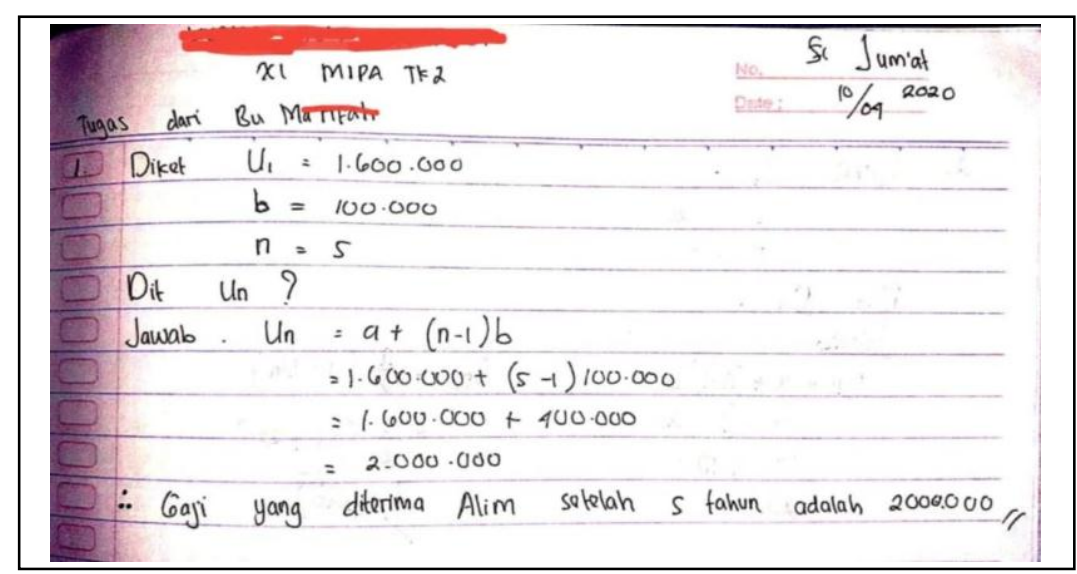

Gambar 4. Jawaban Peserta Didik Berkemampuan Komunikasi Matematis SA pada Soal Nomor 1

Peserta didik SA peserta didik sudah dapat mempresentasikan penyelesaian jawaban secara runtut dan benar berdasarkan gambar 4 di atas. Peserta didik SA juga menuliskan perhitungan secara matematis sesuai rumus barisan dan deret. Peserta didik SA juga telah menggunakan simbol matematis dalam proses penyelesaiannya. Peserta didik juga SA menyimpulkan jawaban dari proses perhitungan dengan bahasa komunikasi peserta didik sendiri dan dapat dipahami dengan baik pada akhir pekerjaan.

Adapun petikan wawancara untuk mengkonfirmasi jawaban peserta didik SA pada gambar 4 adalah sebagai berikut:

$P \quad$ : Apa maksud kamu menuliskan $U_{1}, b$, dan $n$ pada hal-hal yang diketahui?

SA $\quad: U_{1}$ itu a atau suku pertama Bu..., kemudian b itu beda, dan $n$ itu adalah suku yang dicari.

$P \quad:$ : Apa kaitan simbol itu dengan soal?

$S A \quad$ : Ya $U_{1}$ itu berarrti gaji yang pertama kali diperoleh, b itu maksudnya kenaikan gajinya, terus $n$ itu jumlah tahun yang mau dihitung.

$P \quad$ : Kenapa kamu tidak tuliskan keterangan atau penjelasan itu sebelum menulis dalam symbol?

SA : Lha kan biasanya udah pada ngerti Bu simbol itu artinya apa, biasanya di kelas juga langsung begitu dan sudah paham.

$P \quad$ : Misalkan yang baca orang yang tidak paham matematika simbol itu artinya apa, bagaimana?

SA : Iya sih Bu....

Berdasarkan wawancara diperoleh kesimpulan jika peserta didik SA menuliskan hal-hal pada soal cukup dengan simbol matematis, dikarenakan menurut peserta didik SA simbolsimbol tersebut sudah dipahami oleh guru maupun peserta didik sekelas secara umum.

Adapun jawaban SA pada soal nomor 2 ,sebagaimana ditunjukkan pada Gambar 5, peserta didik mengomunikasikan pemikirannya sama dengan soal yang ada pada nomor 1 . Peserta didik menuliskan hal-hal yang diketahui pada soal dengan menggunakan simbol 
matematis secara benar tanpa menjelaskan kaitan simbol dengan masalah pada soal. Peserta didik juga menuliskan hal apa yang ditanyakan pada soal dengan menggunakan simbol matematis yang sesuai tanpa dituliskan kaitannya dengan soal. Adapun jawaban peserta didik secara lengkap dapat dilihat pada Gambar 5.

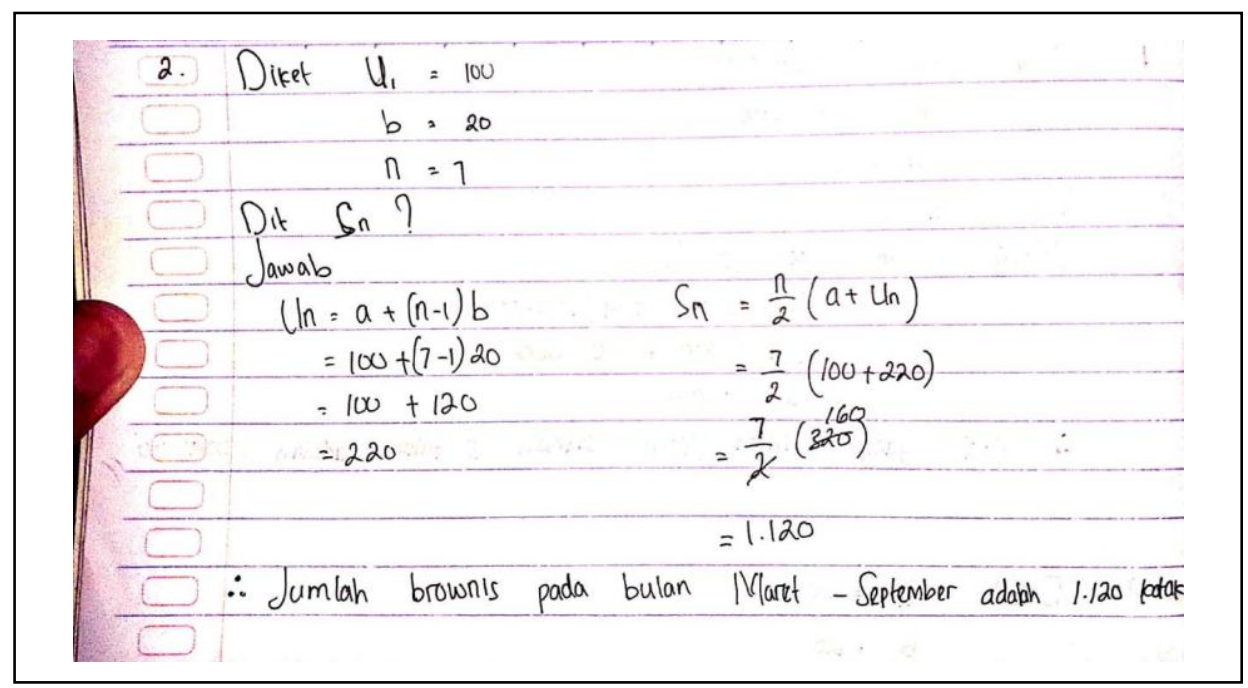

Gambar 5. Jawaban Peserta Didik Berkemampuan Komunikasi SA pada Soal Nomor 2

Berdasarkan jawaban peserta didik SA pada nomor 2 di atas, dapat diamati jika peserta didik dapat mempresentasikan penyelesaian dengan langkah-langkah perhitungan secara runtut. Peserta didik menyajikan penyelesaian dengan dua langkah untuk mempermudah perhitungan dalam langkah selanjutnya. Peserta didik juga menggunakan simbol matematis dalam menyelesaikan masalah yang disajikan dalam rumus secara benar dalam langkah penyelesaian ini. Penulisan kesimpulan dari proses perhitungan juga dilakukan dengan menggunakan bahasa peserta didik SA sendiri dengan penambahan sedikit simbol matematis (titik tiga sebagai representasi kata "jadi").

Hasil wawancara menunjukkan bahwa jika peserta didik SA tidak perlu menjabarkan maksud simbol $U_{1}, b, n, S_{n}$ yang dikaitkan dengan soal. Hal ini dikarenakan penulisan itu sudah bersifat umum dimana guru maupun peserta didik akan mengerti apa maksud simbol itu dengan masalah pada soal.

Hasil pekerjaan peserta didik SA pada nomor 1 dan nomor 2 menunjukkan bahwa peserta didik sudah memenuhi indikator komunikasi yang ditetapkan. Walaupun peserta didik tidak memberikan penjelasan mengenai simbol dengan masalah yang dihadapi. Hal ini dikarenakan adanya persepsi mengenai kesamaan pemahaman antara guru dan peserta didik dalam mengartikan simbol tersebut dengan konten materi barisan dan deret yang telah diajarkan dalam kelas.

Peserta didik kelompok sedang (SD) mulai mengerjakan soal nomor 1 dengan menuliskan yang diketahui dengan menggunakan simbol matematis tanpa menuliskan maksud simbol dengan soal. Kemudian peserta didik SD mempresentasikan penyelesaian 
masalah pada soal tanpa menuliskan apa yang ditanyakan dalam soal cerita. Berikut adalah hasil pekerjaan peserta didik SD.

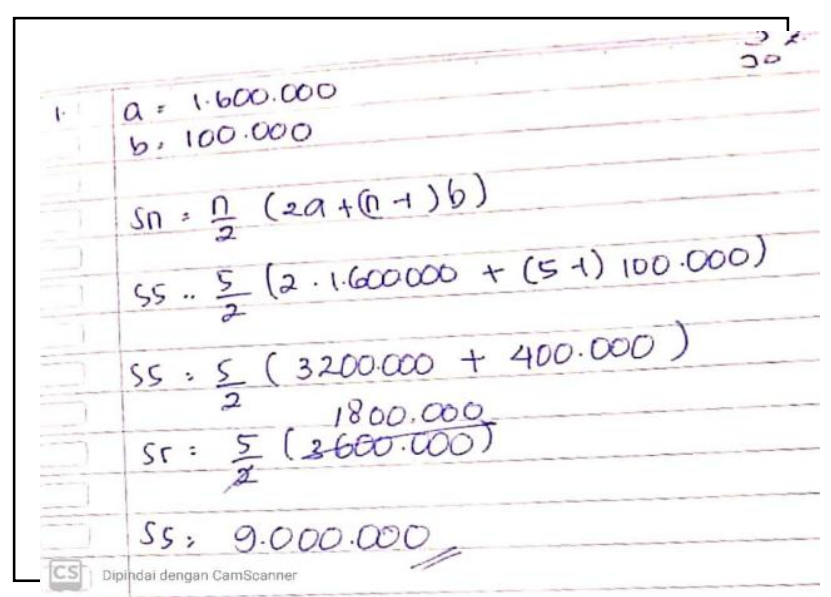

Gambar 6. Jawaban Peserta Didik Berkemampuan Komunikasi Matematis SD pada Soal Nomor 1

Hasil pekerjaan peserta didik SD pada Gambar 6 terlihat bahwa peserta didik belum dapat mempresentasikan rumus yang tepat dalam penyelesaian masalah dan menyebabkan hasil akhir kurang benar. Peserta didik SD juga tidak menuliskan kesimpulan yang dilakukan dari langkah penyelesaian sebelumnya. Dapat dikatakan peserta didik SD memenuhi indikator pertama dan kedua masing-masing hanya pada subindikator pertama saja.

Adapun petikan wawancara pada jawaban gambar 6 di atas adalah sebagai berikut.

$P \quad$ : Apa yang ditanyakan pada soal nomor 1 ?

SB : Gaji selama 5 tahun Bu..

$P \quad:$ Kamu tulis apa tidak yang ditanyakan?

SB : Hehehe... lupa Bu.

$P \quad$ : Terus coba amati soal lagi. Apa benar yang kamu bilang tadi, mencari gaji selama 5 tahun? Apa beda setelah lima tahun dan selama lima tahun?

$S B \quad$ : Oh iya Bu...... Saya salah berarti.

$P \quad$ : terus yang dicari apa berarti?

$S B \quad$ : Gaji setelah 5 tahun, berarti $U_{5}$ ya $B u . . ?$

$P \quad:$ Nah....

SB : Saya salah berarti.

Hasil wawancara diperoleh kesimpulan jika peserta didik SD salah mengerti maksud soal sehingga representasi rumus yang digunakan belum tepat, dan jawaban akhir juga belum tepat. Adapun jawaban SD pada soal nomor 2 sebagaimana ditunjukkan pada gambar 7, peserta didik menuliskan hal-hal yang diketahui dalam simbol matematis secara benar tanpa penjelasan kaitan simbol dengan masalah pada soal. Selanjutnya peserta didik mempresentasikan penyelesain tanpa menuliskan hal apa yang ditanyakan pada soal. Adapun jawaban peserta didik secara lengkap dapat dilihat pada Gambar 7. 


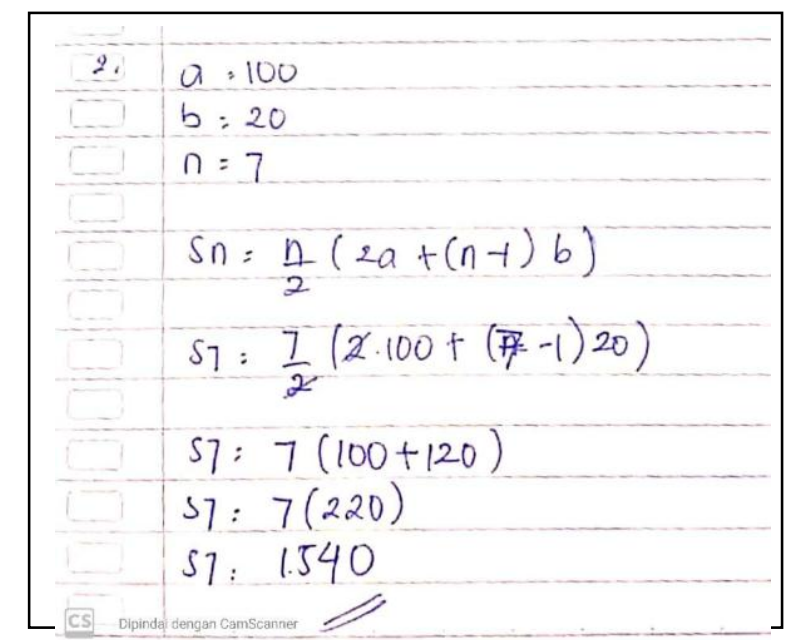

Gambar 7. Jawaban Peserta Didik Berkemampuan Komunikasi Matematis SD pada Soal Nomor 2

Gambar 7 menunjukkan bahwa peserta didik sudah mempresentasikan penyelesaian dengan simbol matematis, namun belum dapat mempresentasikan penyelesaian dengan langkah perhitungan secara runtut dan benar. Adapun perhitungan yang kurang tepat adalah proses pembagian yang melibatkan dua suku, hanya dilakukan pada satu suku. Hal ini mengakibatkan peserta didik belum dapat merepresentasikan jawaban dengan langkah matematis yang benar sehingga hasil akhir juga belum benar. Peserta didik SD juga tidak menuliskan kesimpulan secara matematis maupun dengan bahasanya sendiri. Dapat dikatakan untuk pada indikator 1 maupun indikator 2, peserta didik SD hanya mampu memenuhi subindikator pertama.

Jawaban peserta didik SD pada nomor 2. Peserta didik SD menjelaskan jika menuliskan hal-hal yang diketahui cukup dengan simbol tanpa ada keterangan. Hal ini dikarenakan tanpa ditulis maksud simbol, semua (guru dan peserta didik) sudah mengerti apa arti simbol terhadap soal. Peserta didik SD juga menyadari jika peserta didik melakukan proses perhitungan yang kurang tepat karena melakukan proses pembagian hanya pada satu suku sehingga jawaban akhir juga belum benar.

Peserta didik kelompok bawah (SB) mulai mengerjakan soal nomor 1 dengan menuliskan hal yang diketahui dan yang ditanyakan dengan menggunakan kata-katanya sendiri tanpa simbol matematis. Setelah itu dia menjawab soal dengan penyelesaian yang tidak ada sama sekali hubungannya dengan rumus barisan dan deret. Peserta didik SB juga kurang benar dalam menuliskan kesimpulan. Hasil pekerjaan SB pada nomor 1, ditunjukkan pada Gambar 8. 


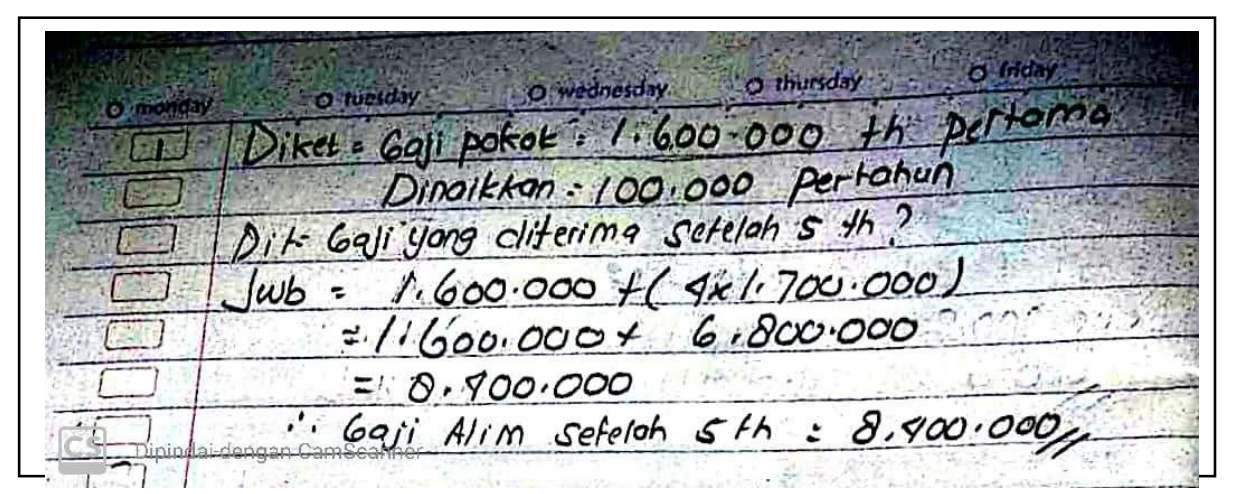

Gambar 8. Jawaban Peserta Didik Berkemampuan Komunikasi Matematis Kelompok SB Soal Nomor 1

Tahap berikutnya adalah wawancara jawaban peserta didik SB dari gambar 8 di atas dengan petikan sebagai berikut:

$P \quad$ : Coba amati pada yang diketahui, gaji pokok dalam soal itu sebagai apa?

$S B \quad$ : Ya gaji awal Bu..

$P \quad$ : lya.. biasanya dilambangkan dengan simbol apa?

SB : Hmm.... a itu ya Bu?

$P \quad$ : Lha tahu kan? Kenapa koq tidak ditulis juga simbolnya? Terus dinaikkan seratus ribu itu apa?

SB : Ya kenaikannya Bu.

$P \quad$ : Kenaikan apa?

$S B \quad$ : Kenaikan gaji.

$P \quad$ : Berarti sebagai apa?

$S B \quad$ : Beda itu ya Bu?

$P \quad$ : lya.... Apa kamu ingat kira-kira apa simbolnya?

$S B \quad: b B u$.

$P \quad$ : Baik. Kemudian bisa menjelaskan hitungan kamu itu bagaimana maksudnya?

$S B \quad$ : Ya gaji tahun pertama ditambah empat tahun setelahnya Bu.

$P \quad:$ : kenapa koq ditambah empat kali satu juta tujuhratus? Kan kenaikannya seratus?

SB : Oooh.. iya Bu saya salah. Berarti seharusnya ditambah empat kali serratus ya?

$P \quad$ : lya.. terus jawaban dan kesimpulan kamu bagaimana?

SB : Berarti salah Bu...

Hasil tes tulis dan wawancara dapat dilihat jika SB belum memenuhi dua indikator pada soal ini. Adapun jawaban SB pada nomor dua, dia juga mengawali mengerjakan dengan menuliskan hal-hal yang diketahui dan kesimpulan dengan bahasa dia sendiri tanpa menggunakan simbol matematis. Peserta didik SB juga tidak menulis apa yang ditanyakan pada soal. Selanjutnya, peserta didik SB merepresentasikan penyelesaian masalah tanpa rumus dan menuiskan jawaban yang kurang tepat. Jawaban akhir peserta didik SB juga belum benar. Hasil pekerjaan SB pada nomor 2, ditunjukkan pada Gambar 9. 


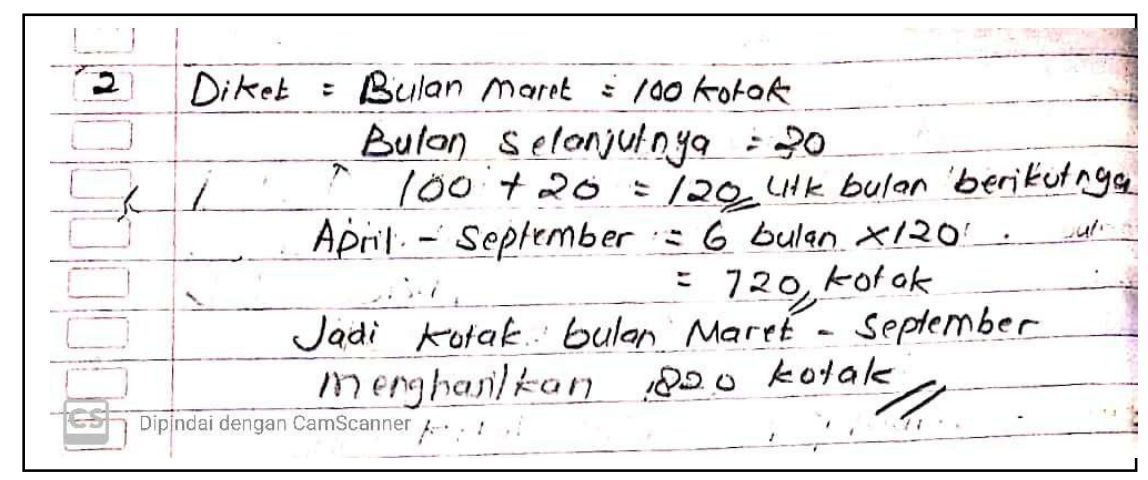

Gambar 9. Jawaban Peserta Didik Berkemampuan Komunikasi Matematis SB pada Soal Nomor 2

Hasil wawancara diperoleh bahwa peserta didik SB memang belum dapat menulis hal-hal yang diketahui dan ditanyakan dengan symbol matematis. Peserta didik SB juga tidak merepresentasikan rumus yang benar karena merasa bingung dan merasa belum bisa menguasai konsep. Jawaban akhir peserta didik SB juga belum benar. Berdasarkan hasil jawaban dan wawancara, dapat disimpulkan jika peserta didik SB memang belum mampu memenuhi semua indikator.

Peserta didik SA sudah mampu memenuhi semua indicator, yakni peserta didik SA sudah dapat 1) mengomunikasikan pemikiran matematis secara koheren dan jelas kepada teman sebaya, guru, maupun pihak lain, dan 2) menggunakan bahasa matematika untuk menyajikan ide matematis secara tepat. Sehingga dapat disimpulkan jika kemampuan komunikasi peserta didik SA sudah baik. Hal ini dapat dilihat dari jawaban peserta didik yang dapat menyampaikan secara jelas apa unsur-unsur yang diketahui dan ditanyakan pada soal sampai dengan kesimpulan. Peserta didik SA juga menggunakan bahasa matematis dengan menggunakan simbol-simbol yang sesuai dan memberikan kesimpulan dengan baik yang merupakan ciri-ciri komunikasi matematika (Persada, 2014; Anintya, 2016; Rahmalia, Hajidin, \& Ansari, 2020).

Peserta didik SD, terlihat jika dia sudah mampu berkomunikasi dengan baik dengan menuliskan hal-hal yang diketahui, ditanyakan dengan baik dan menggunakan simbol matematis. Akan tetapi, SA belum mampu mempresentasikan penyelesaian dengan langkah perhitungan secara runtut dan benar walaupun simbol matematis sudah dia gunakan. Kemampuan untuk menyajikan penyelesaian pemecahan masalah ini harus dimiliki oleh peserta didik, sebab ada korelasi linier konsisten antara pemahaman masalah terhadap proses pemecahan masalah dan keterampilan komunikasi ( Ariawan \& Nufus, 2017; Asmana, 2018; Maharani \& Bernard, 2018).

Peserta didik SB, nampak jika kurang dapat mengomunikasikan apa yang diketahui dan ditanyakan pada soal dengan bahasa baik. Peserta didik SB juga tidak menggunakan 
simbol-simbol matematis sehubungan dengan yang diketahui dan ditanyakan pada konten soal. Ginsburg (dalam Asmana, 2018) menyatakan bahwa peserta didik harus belajar menulis, membaca, dan memahami soal-soal matematika jika mereka ingin menjadi sukses dalam menyelesaikan masalah-masalah matematika. Peserta didik SB juga belum dapat mempresentasikan penyelesaian soal dengan benar dengan menggunakan simbol matematis. Dia tampak mengalami kesulitan dalam memahami makna soal dan belum memahami konsep yang berkaitan dengan soal sehingga Ketika merepresentasikan penyelesaian soal pun kurang baik. Kondisi yang dialami peserta didik SB merupakan suatu kesalahan dapat disebabkan karena ketidaktahuan konsep si subjek, karena untuk memahami makna soal yang telah disajikan, subjek harus menguasai materi dan mengetahui konsep yang berkaitan dengan soal ( Solfitri \& Roza, 2015; Aminah \& Ayu Kurniawati, 2018; Mansur, 2018).

\section{SIMPULAN}

Simpulan hasil penelitian ini bahwa peserta didik berkemampuan matematis tinggi memiliki komunikasi yang baik dan dapat menyelesaikan permasalahan soal cerita dengan hasil akhir yang benar dengan memenuhi semua indikator. Peserta didik berkemampuan sedang memiliki komunikasi yang cukup baik, hanya belum dapat menyajikan penyelesaian dengan baik karena kurangnya kemampuan pemecahan masalah yang dia miliki. Peserta didik berkemampuan rendah memiliki kemampuan komunikasi yang masih kurang, karena belum dapat menuliskan apa yang diketahui dengan benar, tidak menggunakan symbol matematika dengan baik, tidak dapat mempresentasikan jawaban karena pemahaman konsep yang kurang dalam menguasai materi.

\section{DAFTAR PUSTAKA}

Aminah, A., \& Ayu Kurniawati, K. R. 2018. Analisis Kesulitan Siswa dalam Menyelesaikan Soal Cerita Matematika Topik Pecahan Ditinjau dari Gender. JTAM / Jurnal Teori Dan Aplikasi Matematika, 2(2), 118. https://doi.org/10.31764/jtam.v2i2.713

Anintya, Y. A. 2016. Analisis Kemampuan Komunikasi Matematis Ditinjau Dari Gaya Belajar Siswa kelas VIII Pada Model Pembelajaran Resource Based Learning (Doctoral dissertation, Universitas Negeri semarang).

Ariawan, R., \& Nufus, H. 2017. Hubungan Kemampuan Pemecahan Masalah Matematis dengan Kemampuan Komunikasi Matematis Siswa. Jurnal THEOREMS (The Original Research of Mathematics), 1(2).

Asmana, A. T. 2018. Profil Komunikasi Matematika Tertulis dalam Pemecahan Masalah Matematika di SM Ditinjau dari Kemampuan Matematika. Jurnal Inovasi Pendidikan dan Pembelajaran Matematika, 4, 1-12.

Fitriatien, S. R. 2019. Analisis Kesalahan dalam Menyelesaikan Soal Cerita Matematika Berdasarkan Newman. Jurnal IImiah Pendidikan Matematika, 4(1), 53-64. 
Hirschfeld-Cotton, K. 2008. Mathematical Communication, Conceptual Understanding, and Students' Attitudes Toward Mathematics. Action Research Projects, 4, 54. http://digitalcommons.unl.edu/mathmidactionresearch/4

Kaya, D., \& Aydın, H. 2016. Elementary Mathematics Teachers' Perceptions and Lived Experiences on Mathematical Communication. Eurasia Journal of Mathematics, Science and Technology Education, 12(6), 1619-1629.

Lutfianannisak, L., \& Sholihah, U. 2018. Kemampuan Komunikasi Matematis Peserta didik dalam Menyelesaikan Soal Materi Komposisi Fungsi Ditinjau dari Kemampuan Matematika. Jurnal Tadris Matematika, 1(1). https://doi.org/10.21274/jtm.2018.1.1.1-8

Maharani, S., \& Bernard, M. 2018. Analisis Hubungan Resiliensi Matematik Terhadap Kemampuan Pemecahan Masalah Siswa pada Materi Lingkaran. JPMI (Jurnal Pembelajaran Matematika Inovatif), 1(5), 819-826.

Mahmudi, A. 2017. Komunikasi Matematika dalam Pembelajaran Matematika. Logaritma: $\begin{array}{lllll}\text { Jurnal IImu-IImu Pendidikan Dan } & 94 .\end{array}$ https://doi.org/10.24952/logaritma.v5i01.126

Mansur, N. 2018. Melatih Literasi Matematika Siswa dengan Soal PISA. In Prisma, Prosiding Seminar Nasional Matematika (Vol. 1, pp. 140-144).

NCTM. 2000. Principles Standards and for School Mathematics.

Novianti, D. E. 2017. Profil Pemecahan Masalah Matematika dalam Menyelesaikan Permasalahan Pemrograman Linear Ditinjau dari Kemampuan Komunikasi Matematis Mahapeserta didik. JIPM (Jurnal IImiah Pendidikan Matematika), 6(1), 53. https://doi.org/10.25273/jipm.v6i1.1698

Nofrianto, A., Maryuni, N., \& Amri, M. A. 2017. Komunikasi Matematis Siswa. Jurnal Gantang, 2(2), 113-123.

Oktaviana, D. 2017. Analisis Tipe Kesalahan Berdasarkan Teori Newman dalam Menyelesaikan Soal Cerita pada Mata Kuliah Matematika Diskrit. Edu Sains: Jurnal Pendidikan Sains dan Matematika, 5(2), 22-32.

Persada, A. R. 2014. Pengaruh Pendekatan Problem Posing Terhadap Kemampuan Komunikasi Matematika Siswa Kelas Vii. Eduma: Mathematics Education Learning and Teaching, 3(1). https://doi.org/10.24235/eduma.v3i1.2

Qohar, A., \& Sumarmo, U. 2013. Improving Mathematical Communication Ability and Self Regulation Learning of Yunior High Students by Using Reciprocal Teaching. Journal on Mathematics Education, 4(1), 59-74. https://doi.org/10.22342/jme.4.1.562.59-74

Rahmalia, R., Hajidin, H., \& Ansari, B. I. 2020. Peningkatan Kemampuan Komunikasi Matematis dan Disposisi Matematis Siswa SMP Melalui Model Problem Based Learning. Numeracy, 7(1), 137-149.

Riasari, D. 2018. Peranan Model Pembelajaran Matematika Berbasis Blended Learning Terhadap Komunikasi Matematis Siswa dalam Materi Statistik Pada SMAN 1 Tapung. Jurnal Pendidikan Tambusai, 2(2), 813-820. 
Rohid, N., Suryaman, S., \& Rusmawati, R. D. 2019. Students' Mathematical Communication Skills (MCS) in Solving Mathematics Problems: A Case in Indonesian Context. Anatolian Journal of Education, 4(2), 19-30. https://doi.org/10.29333/aje.2019.423a

Solfitri, T., \& Roza, Y. 2015. Analisis Kesalahan dalam Menyelesaikan Soal-Soal Geometri Siswa kelas IX SMPN se-Kecamatan Tampan Pekanbaru. SEMIRATA 2015, 1(1).

Susanti, E. 2017. Penerapan Model Pembelajaran Probing-Prompting untuk Meningkatkan Kemampuan Berpikir Kritis Matematis Siswa Kelas XI. IPA MAN 1 Kota Bengkulu. Jurnal Pendidikan Matematika Raflesia, 2(1).

Triana, M., \& Zubainur, C. M. 2019. Students' Mathematical Communication Ability through the Brain-Based Learning Approach Using Autograph. Journal of Research and Advances in Mathematics Education, 4(1), 1-10.

Viseu, F., \& Oliveira, I. B. 2012. Open-ended Tasks in the Promotion of Classroom Communication in Mathematics. International Electronic Journal of Elementary Education, 4(2), 287-300.

Walk, G., Congress, M., \& Bansho. 2005. Communication in Mathematics Classrooms. Mathematics Education: Exploring the Culture of Learning, 8490, 117-119. https://doi.org/10.4324/9780203465394

Wardhana, I. R. 2018. Analisis Kemampuan Komunikasi Matematis Siswa Ditinjau dari Kemampuan Matematika Peserta Didik. Jurnal Pendidikan Matematika, 6(2), 173184.

Wijayanto, A. D., Fajriah, S. N., \& Anita, I. W. 2018. Analisis Kemampuan Komunikasi Matematis Siswa SMP Pada Materi Segitiga Dan Segiempat. Jurnal Cendekia: Jurnal Pendidikan Matematika, 2(1), 97-104. https://doi.org/10.31004/cendekia.v2i1.36. 